\title{
Mammotome Clip
}

National Cancer Institute

\section{Source}

National Cancer Institute. Mammotome Clip. NCI Thesaurus. Code C47950.

A biocompatible stainless steel tag placed at the site of a breast tissue sample. It appears on a mammogram to help pinpoint an area of past concern. 